\title{
A new species of Lonchophylla Thomas (Chiroptera: Phyllostomidae) from Ecuador
}

\author{
Luis Albuja V. and Alfred L. Gardner \\ (LAV) Departamento de Ciencias Biológicas, Escuela Politécnica Nacional, Apartado 17-01-2759, \\ Quito, Ecuador, e-mail: lalbuja@ server.epn.edu.ecu; \\ (ALG) USGS Patuxent Wildlife Research Center, P.O. Box 37012, National Museum of Natural \\ History, MRC-111, Washington, D.C. 20013-7012, U.S.A., e-mail: gardnera@ si.edu
}

\begin{abstract}
We describe Lonchophylla orcesi, sp. nov., from the Chocó, a region of high biotic diversity, endemism, and rainfall along the western Andean slopes and Pacific lowlands of Colombia and Ecuador. One of the largest known Lonchophylla, it occurs sympatrically with at least two other species of Lonchophylla including the similar, but somewhat smaller L. robusta. We also recognize $L$. concava as a Middle American Province species distinct from $L$. mordax of Brazil and Bolivia on the basis of cranial and dental features.
\end{abstract}

From 1984 to 1988 , personnel representing the Department of Biological Sciences of the Escuela Politécnica Nacional (EPN), Quito, Ecuador, conducted studies and made collections of mammals in the humid tropical forests of northwestern Ecuador. These forests are the southern terminus of the rain forests of the western Andean slopes and adjacent Pacific lowlands of northwestern South America known as the Chocó Association, which is considered to be derived from forest refugia isolated during Pleistocene glacial periods. The Chocó is characterized by high rainfall, high biotic diversity, and a high degree of endemism concentrated in two or three centers (Gentry 1982). A portion of northwestern Ecuador belongs to one of these centers, but despite its biological importance, few biologists have conducted research in the region. Consequently, knowledge of its fauna is poor in comparison with that of other regions in Ecuador.

During this period about 2000 specimens were collected, most of them bats. Among these are 22 specimens of glossophagine bats belonging to the genus Lonchophylla: 4 L. robusta Miller, 1912; 7 L. concava Goldman, 1914 (reported as L. mordax; see below); 7 L. thomasi J. A. Allen, 1904; 3 L. chocoana Dávalos, 2004; and 1 specimen of a species unlike any previously recognized in Lonchophylla. Several reports on additions to the known fauna, descriptions of new species, and the status of conservation in the region, have been published or are under preparation (e.g., Albuja \& Mena 1989, Albuja 1999).

Lonchophylla is distributed from Nicaragua through Costa Rica and Panama into South America to Peru, Bolivia, and southeastern Brazil (Jones \& Carter 1976, Sazima et al. 1978, Koopman 1993). Among the eight species usually recognized today, Albuja (1999) reported five from Ecuador: $L$. mordax Thomas, 1903; L. thomasi J. A. Allen, 1904; L. robusta Miller, 1912; L. handleyi Hill, 1980; and L. hesperia G. M. Allen, 1908. A sixth species that occurs in western Colombia and northwestern Ecuador, L. chocoana Dávalos (2004), is the most recently described. Five of these occur in tropical rainforest habitats in Ecuador and $L$. hesperia is found in the xeric habitats of northwestern Peru and southwestern Ecuador.

We recorded all measurement in millimeters. Those of total length, tail, and ear 


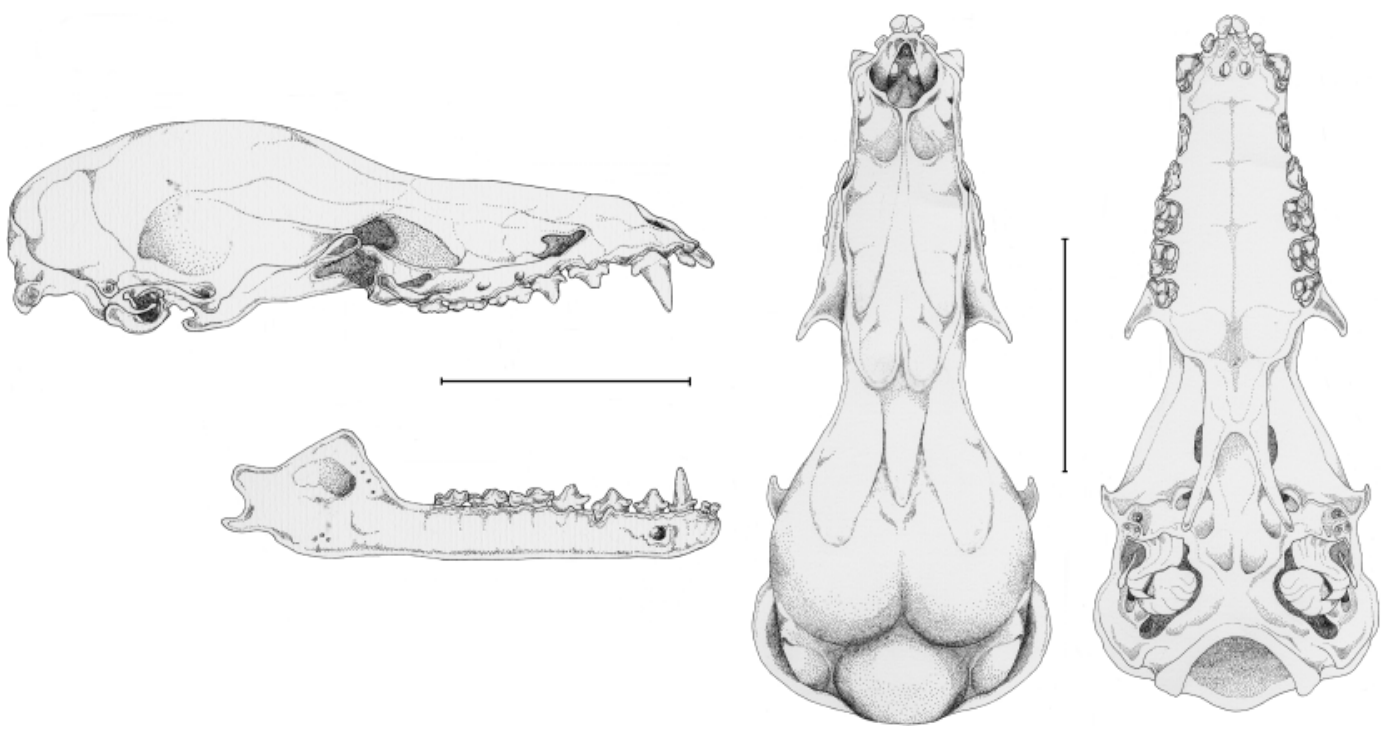

Fig. 1. Illustrations of the skull and ramus of the holotype of Lonchophylla orcesi. The bar equals $10 \mathrm{~mm}$.

were taken in the field on fresh specimens. The other external and cranial measurements were taken in the laboratory with dial calipers under a stereomicroscope. Most of these are standard; however, the following warrant description to avoid misunderstanding:

Length of noseleaf.-From lower edge of horseshoe to tip of the noseleaf.

Greatest length of skull.-From anterior border of premaxillaries to posteriormost extension of the skull.

Depth of braincase.-From lower margin of presphenoid to top of the cranium.

Mandibular length.-From anterior end of ramus to posteriormost margin of the articular condyle.

Height of coronoid.-From ventral margin of ramus to tip of the coronoid process.

Height of ramus.-Height of ramus between first and second molars.

Capitalized colors terms are from the Naturalist's Color Guide (Smith 1975).

We describe our unique specimen of Lonchophylla as:

Lonchophylla orcesi, new species

Holotype.-An adult female, preserved in alcohol with the skull extracted, Escuela
Politécnica Nacional (EPN) number 851241, collected on July 23, 1985 by P. Mena and J. Regalado.

Type locality.-Los Pambiles, $00^{\circ} 32^{\prime} \mathrm{N}$, $78^{\circ} 38^{\prime} \mathrm{W}$, Río Piedras, Cordillera de Toisán, Esmeraldas Province, Ecuador, elevation $1200 \mathrm{~m}$.

Distribution.-Lonchophylla orcesi is known only from the type locality. We assume it inhabits other areas of similar habitat and elevation in northwestern Ecuador.

Etymology.-We name this species in honor of Prof. Gustavo Orcés V. (19031996), a distinguished zoologist and pioneer of Ecuadorian research on vertebrates, and former director of the Department of Biological Sciences of the Escuela Politécnica Nacional.

Diagnosis.—Lonchophylla orcesi equals or exceeds the size of L. chocoana, L. handleyi, and L. robusta in most dimensions, especially in cranial linear dimensions, which reflect its much longer rostrum. With a greatest length of skull (not including incisors) of $30.4 \mathrm{~mm}$ and a forearm length of $47 \mathrm{~mm}$, Lonchophylla orcesi exceeds the size of all other known species of Lonchophylla. The interfemoral membrane is longer (Table 1) than in the other larger spe- 
Table 1.-Measurements ( $\mathrm{mm}$ ) of Lonchophylla orcesi, L. robusta, and L. chocoana.

\begin{tabular}{|c|c|c|c|}
\hline Measurements & $\begin{array}{c}\text { L. orcesi } \\
1 \text { (holotype) female }\end{array}$ & $\begin{array}{l}\text { L. robusta } \\
\text { EPN } 5 \text { females, } 3 \text { males }\end{array}$ & $\begin{array}{l}\text { L. chocoana }{ }^{2} \\
\text { Holotype and paratype } 2 \text { females }\end{array}$ \\
\hline Total length & 72.0 & $72.8(67.0-78.0)$ & $81.3(78.0-84.5)$ \\
\hline Tail vertebrae & 11.0 & $10.0(8.2-12.0)$ & $8.8(7.0-10.5)$ \\
\hline Foot & 14.8 & $11.2(10.0-14.0)$ & $14.1(13.2-15.0)$ \\
\hline Ear from notch & 17.0 & $15.0(14.0-16.0)$ & $15.5(14.0-17.0)$ \\
\hline Forearm & 47.0 & $43.6(42.7-45.1)$ & $46.5(45.0-48.0)$ \\
\hline Tibia & 18.3 & $16.7(15.8-17.7)$ & $17.4(16.5-18.2)$ \\
\hline Mass & 22.0 & $17.2(14.0-19.5)$ & $21.0(19.0-23.0)$ \\
\hline Length of noseleaf ${ }^{1}$ & 6.6 & $7.4(7.0-7.6)$ & \\
\hline Breadth of noseleaf ${ }^{1}$ & 5.1 & $5.2(5.1-5.2)$ & \\
\hline Length of interfemoral membrane ${ }^{1}$ & 18.3 & $15.3(14.4-16.0)$ & $12.5(12.4-12.6)^{3}$ \\
\hline Greatest length of skull & 30.4 & $26.9(26.0-27.9)$ & $27.8(27.2-28.3)$ \\
\hline Condylobasal length & 29.7 & $25.6(24.5-26.6)$ & $26.8(26.1-27.3)^{3}$ \\
\hline Least postorbital constriction & 5.6 & $5.3(4.9-5.5)$ & $5.3(5.3)$ \\
\hline Braincase breadth & 11.1 & $10.0(9.5-10.9)$ & $10.4(10.2-10.5)$ \\
\hline Braincase depth & 7.9 & $7.8(7.6-8.0)$ & $8.2(8.1-8.3)^{3}$ \\
\hline Mastoid breadth & 12.7 & $11.0(10.6-11.5)$ & $11.7(11.3-12.0)^{3}$ \\
\hline Palatal length & 17.9 & $15.0(14.2-15.5)$ & $15.7(15.5-15.8)$ \\
\hline Length maxillary toothrow & 11.3 & $10.4(10.0-10.9)$ & $10.8(9.8-11.7)$ \\
\hline Breadth across molars & 7.4 & $6.5(5.3-6.9)$ & $7.2(7.0-7.5)^{3}$ \\
\hline Breadth across canines & 4.8 & $4.1(3.8-4.5)$ & $4.4(4.2-4.8)^{3}$ \\
\hline Height of canine & 2.5 & $2.5(2.3-2.6)$ & $2.7(2.6-2.7)$ \\
\hline Length of mandible & 22.2 & $19.1(18.2-20.0)$ & $19.2(19.0-19.3)^{3}$ \\
\hline Length of mandibular toothrow & 11.8 & $10.6(10.4-10.8)$ & $10.3(10.0-10.6)^{3}$ \\
\hline Coronoid height & 5.9 & $5.1(4.7-5.5)$ & $5.5(5.2-5.6)^{3}$ \\
\hline Depth of ramus & 2.4 & $1.9(1.6-2.1)$ & $2.3(2.1-2.5)^{3}$ \\
\hline
\end{tabular}

${ }^{1}$ Measurements of fluid-preserved specimens.

${ }^{2}$ Dávalos, 2004, except as noted.

${ }^{3}$ Measurements of EPN 851218, 851232, and USNM 575171 from Ecuador.

cies; the upper canines are robust, but not as long as in L. chocoana; and the upper inner incisors are especially long, procumbent, and have spatulate tips (Fig. 1).

Description.-Lonchophylla orcesi is one of the larger species of the genus (forearm, $47 \mathrm{~mm}$; greatest length of skull (not including incisors), $30.4 \mathrm{~mm}$; condylobasal length, 29.7; palatal length, 17.9; maxillary toothrow, $11.3 \mathrm{~mm}$; mass, $22 \mathrm{~g}$ ). The ears are short $(17 \mathrm{~mm})$. The tragus is broad, its medial margin thick and curved, and its external (posterior) border thin, almost straight, and with a small indentation or nick at the midpoint. The noseleaf is covered with fine hairs and measures $6.6 \mathrm{~mm}$ long and $5.1 \mathrm{~mm}$ wide. As in other members of the genus, the lower lip has a deep medial furrow bordered with small tubercles. The snout has many vibrissae and oth- er tactile hairs. The interfemoral membrane is long $(18.3 \mathrm{~mm})$ and lacks a fringe of hair on its border. The tail extends a little more than half the length of the interfemoral membrane; its tip projects from the upper surface and is sparsely covered with short hairs. The calcar is short $(5.5 \mathrm{~mm})$, the feet are long $(14.8 \mathrm{~mm})$ and clothed with thinly scattered hairs, and the toes bear strong, curved claws.

Dorsal coloration is pale brown, darkest on the head, and the color of the basal band of pelage is whitish. Pelage of the venter is shorter, a paler yellowish gray-brown, and individual hairs are gray at the base. The ears, noseleaf, tragus, and interfemoral membrane are blackish. The pelage is thick and extends onto the proximal two-thirds of the forearm. The distal third of the forearm is clothed with small, scattered hairs, and 
there is a tuft of hair at the base of the thumb.

The skull is long $(30.4 \mathrm{~mm})$ with an especially elongated rostrum as reflected by the lengths of palate and maxillary toothrow (17.9 and $11.3 \mathrm{~mm}$, respectively; see Table 1). The rostrum, anterior to the postorbital constriction, comprises almost half the total length of skull. The braincase is relatively low, but broad as reflected by breadths of braincase and mastoid (11.1 $\mathrm{mm}$ and $12.7 \mathrm{~mm}$, respectively). The dentaries protrude anterior to the lower incisors forming a chin. The upper inner incisors are large, spatulate, strongly procumbent, and separated basally, but in contact at their tips. The upper outer incisors are smaller and more slender than the inner, and evenly spaced between the inner incisors and canines. The lower incisors are undifferentiated, oriented vertically, and the outer incisors are separated from the canine by a space nearly equal to their crown width. The canines are robust, but not especially long (height of crown, $2.5 \mathrm{~mm}$ ). The upper premolars are triangular in lateral view, the first well separated from the canine. The central cuspids of the lower premolars are high, the first lower premolar is in contact with the canine and its anterior margin is slightly convex, but its posterior margin is concave with a posterior cuspule similar to that of the second lower premolar. The lower molars decrease in size posteriorly (Fig. 1).

Comparisons. - Lonchophylla orcesi is a member of the Chocoan fauna of Ecuador and Colombia where it is sympatric with $L$. chocoana and L. robusta. The only other large Lonchophylla in Ecuador is L. handleyi, which is a member of the upper (western) Amazon basin fauna. Lonchophylla orcesi differs from these species in having a longer skull, wider braincase and postorbital constriction, longer maxillary toothrow, longer mandible, absolutely and relatively longer rostrum, and longer interfemoral membrane (Fig. 1, Table 1). In contrast to $L$. chocoana, the rostrum of $L$. or- cesi is narrower and more delicate, its braincase is less elevated, and its interfemoral membrane is wider. In all respects, $L$. orcesi is more similar to $L$. robusta than it is to L. chocoana. Lonchophylla orcesi differs from $L$. robusta in having a much longer rostrum, larger and more procumbent inner upper incisors, larger and higher central cuspids of lower premolars, a more protruding chin, and larger and stronger feet and claws. The canines are not especially long in comparison with those of $L$. robusta and L. chocoana.

Habitat._Lonchophylla robusta, L. orcesi, and L. chocoana were netted together on a small, flat, densely forested river terrace at Los Pambiles on the banks of the Río Piedras. The canyon of the Río Piedras is a topographically diverse area in foothills of the Cordillera de Toisán. The collection site is in the Reserva Ecológica CotacachiCayapas, classed as part of the Subtropical Zoogeographic Region (Albuja et al. 1980), and according to the ecological map of Cañadas (1983), as Very Humid Pre-montane Forest (bmhPM). This forest has at least two relatively undifferentiated strata. The canopy of the upper stratum is open and discontinuous; that of the lower stratum is denser and nearly continuous. The trees have relatively slender trunks and reach heights of 15 to $25 \mathrm{~m}$. Young palms and saplings of other trees are plentiful in the understory, which includes tree ferns, and mosses. Epiphytes, which include largeleaved Araceae, orchids, and bromeliads, are conspicuous. This region, with a mean annual temperature of about $20^{\circ} \mathrm{C}$, has high humidity and the annual precipitation can exceed $4000 \mathrm{~mm}$.

\section{The status of Lonchophylla concava Goldman, 1914}

During the course of preparing this report, we were concerned with the identity of the other two species of Lonchophylla found in lowland and Andean slope forests of northwestern Ecuador. Albuja (1999) re- 
Table 2.-Measurements ( $\mathrm{mm}$ ) of Lonchophylla concava, L. mordax, and L. thomasi.

\begin{tabular}{lccc}
\hline \multicolumn{1}{c}{ Measurements } & L. concava $^{1}$ & L. mordax $^{2}$ & L. thomasi $^{4}$ \\
\hline Forearm & $32.0-34.6$ & $34.0-37.2$ & $31.0-33.3$ \\
Condylobasal length & $20.8-22.4$ & $20.4-20.6^{3}$ & $18.3-20.4$ \\
Condyloincisive length & $21.3-22.9$ & $20.7-21.0^{3}$ & $18.9-21.2$ \\
Palatal length & $11.8-12.9$ & $11.3-11.7$ & $10.8-12.0$ \\
Zygomatic breadth & $8.8-9.4$ & $8.7-9.3$ & $8.5-9.4$ \\
Least postorbital constriction & $4.2-4.6$ & $4.1-4.6$ & $4.0-4.2$ \\
Braincase breadth & $8.6-9.1$ & $8.3-8.4^{3}$ & $8.2-8.8$ \\
Mastoid breadth & $9.1-9.6$ & $8.5-9.0^{3}$ & $8.5-9.3$ \\
Breadth across canines & $3.5-3.9$ & $3.4-3.7^{3}$ & $3.6-4.2$ \\
Breadth across molars & $5.0-5.3$ & $4.8-4.9^{3}$ & $4.8-5.3$ \\
Length maxillary toothrow & $7.4-7.9$ & $7.5-7.9$ & $6.2-7.0$ \\
Length mandibular toothrow & $7.8-8.4$ & $7.9-8.1$ & $6.6-7.3$ \\
\hline${ }^{1} N=13$. & & & \\
${ }^{2} N=4$, except as noted. & & & \\
${ }^{3} N=3$. & & & \\
${ }^{4} N=14$. & & &
\end{tabular}

ported these taxa as L. mordax and L. thomasi. Lonchophylla thomasi is a small species of Lonchophylla found throughout the greater Amazon basin and northern South America. It occurs in Ecuador and Colombia on both sides of the Andes and is in Central America at least as far north as Costa Rica. Lonchophylla thomasi has not been reported in eastern or southeastern Brazil where the species L. bokermanni, L. dekeyseri, and L. mordax are known to occur.

As currently recognized in the literature, the species L. mordax has a disjunct distribution with a Middle American Province component found from northwestern Ecuador to Costa Rica, and a Brazilian and eastern Bolivian component found mainly in eastern Brazil from eastern Pará south to the state of Espírito Santo. Goldman (1914) described the Middle American Province population as Lonchophylla concava with the type locality Cana, Darién, Panama. Handley (1966), based on the strong similarity with L. mordax Thomas, 1903 (type locality Lamarão, Bahia, Brazil), synonymized L. concava under L. mordax and used the name combination Lonchophylla mordax concava for the Panamanian population. Contrary to Handley's (1966) conclusion, our direct comparison reveals a se- ries of trenchant differences between specimens from northwestern South America and specimens from eastern Bolivia and eastern Brazil, including a specimen from the type locality of L. mordax. Therefore, we consider the northwestern South American and southern Central American population to represent the species Lonchophylla concava, thereby restricting the name $L$. mordax to the Brazilian and eastern Bolivian populations.

These two species are superficially similar in size (Table 2) and shape, and it is easy to understand why Handley (1966) treated them as a single species. Major differences, however, are evident in the morphology of the rostrum, palate, coronoid process, and the last upper premolar (P4). Lonchophylla concava can be distinguished from L. mordax by its very small to obsolete lingual cuspule on the last upper premolar and the lack of evidence for root support for that cusp (lingual cuspule small to prominent, and always rooted in L. mordax); posterior margin of antorbital foramen within the relatively smooth contour of the lateral margin of the rostrum (posterior margin projects out from lateral margin of the rostrum in L. mordax); median furrow in palate transitions through an elongated 
pit-like groove before it merges with the nearly flat terminal portion of the post-dental palate (median furrow transitions smoothly onto terminal post-dental palate in L. mordax); medial posterior projection of palate into mesopterygoid fossa usually absent (medial projection usually present in $L$. mordax); space between second lower incisor and canine usually as wide as or wider than width of crown of second lower incisor (space usually narrower than width of crown of second lower incisor in L. mordax); the first lower premolar (p2) large, blade-like, its posterior cuspulid reduced (p2 not blade like, its posterior cuspulid similar in development to that of p3 in $L$. mordax); and coronoid process low and broadly (anteriorly-posteriorly) rounded (coronoid process always angular in L. mordax). The skull is a little longer in $L$. concava and the braincase tends to be wider than in L. mordax (see Table 2); otherwise, cranial dimensions seem to be similar. Taddei et al. (1983) accurately described $L$. concava and used the configuration of the last upper premolar in their identification key to distinguish L. mordax mordax from L. mordax concava, which we treat as a species separate from $L$. mordax.

\section{Discussion}

The tropical rain forests of the coastal and lower Andean slopes of western Colombia and Ecuador have been isolated from the Amazon forests for more than four million years by the Andean barrier (Prance 1982). Largely because of this isolation, a highly endemic and still poorly-known fauna has evolved. Prior to the mid to late 1960 s, lack of access protected the northwestern region of Ecuador. While this isolation impeded research, it also limited forest conversion and general degradation of the ecosystem. With the opening of the Santo Domingo de los Colorados-Esmeraldas highway in 1960 and completion of the Ibarra-San Lorenzo railroad in 1969, colo- nization surged, and the areal extent of forest habitat has declined dramatically.

Los Pambiles, the site where L. chocoana, L. orcesi, and L. robusta were collected, is within the Reserva Ecológica Cotacachi-Cayapas. Other species of bats known to inhabit this area are Anoura geoffroyi, A. caudifer, Rhinophylla alethina, Platyrrhinus vittatus, Artibeus glaucus, Sturnira bidens, and Sturnira spp.

Efforts to collect additional specimens were unsuccessful. Nevertheless, because our single specimen is characterized by distinctive characters that easily distinguish it from all other known species of Lonchophylla, we do not hesitate to name and describe it as a new species, $L$ orcesi.

Finding two previously unknown species in the same genus (L. chocoana and L. orcesi) at the same locality is a noteworthy indication of how poorly the biota of the area is known. Albuja (1999) reported $L$. chocoana as Lonchophylla Sp. A; and $L$. orcesi as Lonchophylla Sp. B. Lonchophylla chocoana, L. orcesi, and L. robusta are sympatric at the type locality of $L$. orcesi, and $L$. concava and $L$. thomasi also occur in the region. Each of these species has unique cranial and dental characteristics, probably as a result of adaptations to lessen competition because of their similar diets. Studies on the subtleties of resource partitioning among these bats should prove fascinating.

Ascorra et al. (1989) reported L. concava from two localities in the valley of the lower Palcazú, Pasco, Peru, at or near 375 m in the eastern foothills of the Andes. The forearm measurement they gave $(39.0 \mathrm{~mm})$ is too large for either $L$. concava (which is not known east of the Andes) or L. mordax, and we suggest that the specimens should be reexamined. Ascorra et al. (1994) reported 7 males and 11 female L. mordax from Jenaro Herrera in the eastern lowlands of Loreto, Peru. The forearm measurements they gave range from 29.7 to $37.6 \mathrm{~mm}$, and are within the range for L. mordax. We also suggest that these specimens be reexamined 
because of the great distance between this site and the closest distributional records for L. mordax in Brazil and Bolivia. The geographically closest confirmed record for $L$. mordax is from Parque Nacional Noel Kempff Mercado in eastern Santa Cruz, Bolivia (Louise H. Emmons, pers. comm.), an airline distance of approximately $1800 \mathrm{ki}-$ lometers. We have examined a specimen in the University of Kansas Museum of Natural History (KU 144232) from Peru that may represent the species reported by Ascorra et al. (1989, 1994). Although similar to larger L. mordax in size and some morphological features, it has a shorter rostrum and its pale, reddish brown pelage matches that of $L$. handleyi and L. robusta. This specimen either represents an undescribed species or is a western representative of $L$. dekeyseri.

\section{Acknowledgments}

We are grateful to the personnel of the Ecuadorian Departamento de Parques Nacionales y Vida Silvestre, Ministerio de Agricultura y Ganadería, for their cooperation and assistance during the fieldwork. Licenciados Patricio Mena and Jhanira Regalado of the Universidad Central, Quito, collaborated in the execution of the research project, particularly in the fieldwork. This research was financed in part under a cost-sharing agreement between the Escuela Politécnica Nacional and Fundación Nacional de Ciencia y Tecnología del Ecuador (FUNDACYT) for biological surveys of the fish and mammals of northwestern Ecuador.

\section{Literature Cited}

Albuja, L. 1999. Murciélagos del Ecuador, 2nd edition. Cicetronic Companía, Limitada, Quito, Ecuador, 288 pp. +19 unpaged plates.

, \& P. Mena. 1989. Adiciones a la fauna de Quirópteros del Noroccidente del Ecuador-Revista Politécnica 14(2):105-111.

, M. Ibarra, J. Urgilés, \& R. Barriga. 1980. Estudio preliminar de los Vertebrados Ecuatorianos. Escuela Politécnica Nacional. Departamento de Ciencias Biológicas, Quito, 143 pp.
Allen, G. M. 1908. Notes on Chiroptera.-Bulletin of the Museum of Comparative Zoölogy 52:25$62,1 \mathrm{pl}$.

Allen, J. A. 1904b. New bats from tropical America, with note on species of Otopterus.-Bulletin of the American Museum of Natural History 20: 227-237.

Ascorra, C. F., D. L. Gorchov, \& F. Cornejo. 1989. Observaciones en aves y murciélagos relacionadas con la dispersion de semillas en el valle Palcazu, Selva Central del Perú.-Boletín de Lima 62:91-95.

— —,$\&-1994$ (1993) The bats from Jenaro Herrera, Loreto, Peru.-Mammalia 57:533-552.

Cañadas, L. 1983. El Mapa Bioclimático y Ecológico del Ecuador--MAG-PRONAREG. Quito.

Dávalos, L. A. 2004. New chocoan species of Lonchophylla (Chiroptera: Phyllostomidae).American Museum Novitates 3426:1-14.

Gentry, A. H. 1982. Phytogeographic Patterns as Evidence for a Chocó Refuge. Pp. 112-136 in G. T. Prance, ed., Biological diversification in the tropics. Columbia University Press, New York.

Goldman, E. A. 1914. Descriptions of five new mammals from Panama.-Smithsonian Miscellaneous Collections 63(5):1-7.

Handley, C. O., Jr. 1966. Checklist of the mammals of Panama. Pp. 753-795 in R. L. Wenzel and V. J. Tipton, eds., Ectoparasites of Panama, Field Museum of Natural History, Chicago.

Hill, J. E. 1980. A note on Lonchophylla (Chiroptera: Phyllostomatidae) from Ecuador and Peru, with the description of a new species. Bull. British Mus. Nat. Hist. (Zool.) 38:233-236.

Jones, J. K., \& D. C. Carter. 1976. Annotated checklist with keys of subfamilies and genera. Pp. 7-38 in R. J. Baker, J. K. Jones, and D. C. Carter, eds., Biology of bats of the New World family Phyllostomatidae Part I.-Special Publication, The Museum, Texas Tech University, number 10.

Koopman, K. F. 1993. Order Chiroptera. Pp. 137-241 in D. Wilson and D. M. Reeder, eds., Mammal species of the World, 2nd edition. Smithsonian Institution Press, Washington, D.C.

Miller, G. S. 1912a. A small collection of bats from Panama.-Proceedings of the United States National Museum 42(1882):21-26.

Prance, G. T. 1982. Forest refuges: evidence from woody angiosperms. Pp. 137-158 in G. T. Prance, ed., Biological diversification in the tropics. Columbia University Press, New York.

Sazima, I., L. D. Vizotto, \& V. A. Taddei. 1978. Uma nova especie de Lonchophylla da Serra do Cipó, Minas Gerais, Brasil (Mammalia, Chiroptera, Phyllostomidae).-Revista Brasileira de Biología 38:81-89. 
Smith, F. B. 1975. Naturalist's color guide. The American Museum of Natural History, New York

Taddei, V. A., L. D. Vizotto, and I. Sazima. 1983. Uma nova espécie de Lonchophylla do Brasil e chave para identificação das especies do genero (Chiroptera, Phyllostomidae).-Ciência e Cultura 35:625-629.

Thomas, O. 1903. Notes on South-American monkeys, bats, carnivores, and rodents, with descriptions of new species.-Annals and Magazine of Natural History, series 7 12:455-464.

Associate Editor: Gary R. Graves

Appendix

Specimens examined

The following specimens are deposited in the National Museum of Natural History, Washington, D.C., U.S.A. (USNM); the Museum of Natural History, University of Kansas, Lawrence (KU); the Escuela Politécnica Nacional, Quito, Ecuador (EPN); and an uncatalogued collection made by Louise Emmons (LHE).

Lonchophylla concava (17): COLOMBIA, Valle del Cauca, Río Zabaletas, $29 \mathrm{~km}$ SE of Buenaventura (USNM 483360). COSTA RICA, Puntarenas, Quebrada Camaronal, near Sirena Station, Corcovado National Park (USNM 565809). ECUADOR, Pichincha, Palenque Science Center (USNM 528494-528500). PANAMA, Chiriquí, $1 \mathrm{mi}$. E of Cuesta de Piedra (USNM 331254); Darién, Cana (USNM 179621, holotype); Tacarcuna Village Camp (USNM 309384-309386, 309388, 309389); San Blas, Quebrada Repressa, Puerto Obaldía (USNM 335179).
Lonchophylla chocoana (2): COLOMBIA, Valle del Cauca, Río Zabaletas, $29 \mathrm{~km}$ SE of Buenaventura (USNM 483361, 483362). ECUADOR, Esmeraldas, Los Pambiles, Cordillera de Toisán (EPN 851218, 851232, USNM 575171).

Lonchophylla handleyi (2): PERU, Junín, Río Tulumayo, $3.2 \mathrm{~km} \mathrm{~N}$ of Vitoc (USNM 507172); Pasco, San Juan (USNM 364247).

Lonchophylla hesperia (1): PERU, La Libertad, Trujillo (USNM 283177).

Lonchophylla mordax (4): BRAZIL, Bahia, Lamarão (USNM 123392); Cidade da Barra (USNM 238008). BOLIVIA, Santa Cruz, Huanchaca I (LHE 1630, 1638).

Lonchophylla orcesi (1): ECUADOR, Esmeraldas, Los Pambiles (EPN 851241, holotype).

Lonchophylla robusta (9): ECUADOR, Guayas, San Rafael, $7 \mathrm{~km} \mathrm{~S}$ of Balao (USNM 498827-498829); Huerta Negra, $10 \mathrm{~km}$ ESE of Balao (USNM 522157); Huerta Negra, $20 \mathrm{~km}$ ESE of Balao (USNM 498830, 498831, 534298-534300).

Lonchophylla thomasi (12): COLOMBIA, Valle del Cauca, Río Zabaletas, $29 \mathrm{~km}$ SE of Buenaventura (USNM 483359, 483363-483365). ECUADOR, Orellana, Yasuní 2, ca. $00^{\circ} 56^{\prime} \mathrm{S}, 75^{\circ} 57^{\prime} \mathrm{W}$ (USNM 528325); Pastaza, $130 \mathrm{mi} \mathrm{S}$ of Coca, $01^{\circ} 07^{\prime} \mathrm{S}$, $76^{\circ} 57^{\prime} \mathrm{W}$ (USNM 574510, 574511). GUYANA, Barima-Waini, Baramita (USNM 582299-582301). PERU, Ucayali, $59 \mathrm{~km} \mathrm{SW}$ of Pucallpa (USNM 499018); Cuzco, La Convención Camisea, Armihuarí (USNM 582795).

Lonchophylla sp. (1): PERU, Madre de Dios, Reserva Cuzco Amazónico, 15 km E of Puerto Maldonado (KU 144232). 